\title{
PRÍSPEVOK K DEJINÁM VÝSKUMU LOKALÍT Z DOBY BRONZOVEJ V DOMANÍKOCH A SEBECHLEBOCH ${ }^{1}$
}

\author{
Gabriel Nevizánsky - Péter Prohászka
}

DOI: https://doi.org/10.31577/szausav.2019.suppl.1.21

Keywords: Middle Slovakia, Domaníky, Sebechleby, Ede Boleman, archivals, Final Bronze Age, research history

\section{Data to the research history of the Bronze Age sites at Domaníky and Sebechleby}

The article deals with the research history of the Final Bronze Age cemetery in Domaníky. The cemetery is well known thank to Andrej Kmet'. He excavated and collected here a lot of urns and bronze objects in 1887. Kmet' published the finds and the results in the periodical Tovaryšstvo. But the first finds from Domaníky came to the private collection of the notary Rezső Keller and he reported first about the cemetery. He gave them with other finds together from Szebelléd as a gift to the Hungarian National Museum. The clay bowl with decorations is dated to Ha B stage. Very important is an other object from Sebechleby, a bronze tool, which was used at minning in prehistory. On the occasion of the International Congress of the Prehistoric Archaeology and Anthropology in 1876 made Ede Boleman a short excavation in the cemetery. He sent the digged artefacts to the Hungarian National Museum, but the finds are missing in the collection. His excavation report was published in the daily newspaper "Hon". After presenting the biography of Ede Boleman the autors anlyzed and evaulated the remained objects and reports.

\section{ÚVOD}

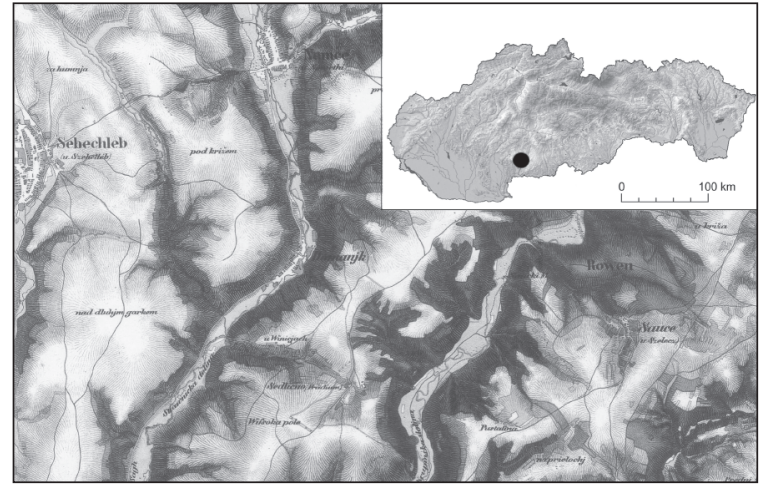

Obr. 1. Okolie Sebechlieb a Domaník na mapovom liste druhého vojenského mapovania.
Hontianska obec Domaníky, okr. Krupina, sa dostala do povedomia archeologickej odbornej verejnosti vd’aka aktivitám A. Kmeta, ktorý v jeho katastri realizoval v roku 1887 terénny výskum (obr. 1). Na sledovanej lokalite odkryl urnové hroby z neskorej doby bronzovej. Svoje terénne pozorovania a nálezové okolnosti zachránených hrobov vrátane nájdených artefaktov dokumentoval aj fotografiami v druhom ročníku časopisu „Tovaryšstvo“ (Kmet' 1895). Počiatky archeologického výskumu v Domaníkoch slovenská odborná verejnosṫ doposial' spája s osobnostou A. Kmeta napriek tomu, že už takmer jedno desatročie pred ním sa dostali informácie na svetlo sveta o tunajších nálezoch, z ktorých niekol'ko sa dostalo aj do zbierkového fondu Mad’arského národného múzea. Dokonca pred Kmetom, už v roku 1876 uskutočnili v Domaníkoch archeologický výskum, ako nás o tom informuje článok v súdobých novinách.

Na sledovanú lokalitu upozornil F. Rómera a zároveň aj Archeologickú komisiu už v roku 1870 R. Keller, o čom informuje krátka správa v časopise Archaeológiai Értesítő (Rómer 1870, 98): „(Domaníky, hontianska župa) na konopných poliach sa často nachádzajú hrnce s rozmermi až do troch palcov, ktoré pospolitý l’ud zväčša porozbija. Na tomto pohrebisku často nachádzajú bronzové predmety a spálené kosti. Za túto informáciu sme vd’ačný pánovi Rudolfovi Kellerovi a zároveň lokalitu venujeme do pozornosti Hontianskej archeologickej spoločnosti." O sledovanom nálezisku bola informovaná hore uvedená organizácia, ktorá však vtedy sotva 
mohla uskutočnit výskum. Založili ju síce už v roku 1834, ale po relatívne krátkom pôsobení v roku 1847 zanikla a svoje zbierky odovzdala do fondu Madarského národného múzea (Prohászka 2018). Namiesto hontianskej inštitúcie však výskum inicioval tekovský, konkrétnejšie levický lekárnický spolok na čele s lekárnikom E. Bolemanom. Menovaný o šest’ rokov neskôr, koncom augusta 1876, navštívil lokalitu, kde realizoval aj krátkodobý terénny výskum.

Levický lekárnik E. Boleman (1835-1884) popri svojej archeologickej činnosti v Tekove zohral významnú rolu v hospodárskom a politickom živote mesta (obr. 2). V čase úmrtia bol riaditelom Levickej sporitelne a úverového ústavu, dalej poslancom mestského magistrátu a členom viacerých vedeckých spoločností (b. a. 1884). Počiatky jeho záujmu o archeológiu siahajú do 60. rokov 19. stor., kedy ako člen Lekárnického spolku Tekovskej župy realizoval terénne výskumy a zbieral starožitnosti hlavne z územia Tekovskej a Hontianskej župy. Jeho najvýznamnejšie vedecké aktivity sa viažu k eponymnej lokalite mad’arovskej kultúry v katastri niekdajšej obce Mad’arovce, dnes miestna časṫ obce Santovka, okr. Levice. E. Boleman z poverenia Lekárskeho spolku Tekovskej župy kopal $\mathrm{s}$ nádenníkmi v Madarovciach na viacerých miestach na vrchole vyvýšeniny (Boleman 1870, 107). Nájdené zvyšky zoologického materiálu poslali Archeologickej komisii Mad’arskej akadémie vied (Báthory 1866). O výsledkoch svojho výskumu E. Boleman referoval v liste, ktorého text sprístupnil F. Rómer na stránkach časopisu Archaeológiai Értesítő (Boleman 1870). Následne hore uvedený spolok v Mad’arovciach nájdené nálezy v roku 1869 daroval do fondu Madarského národného múzea (Nevizánskyl Prohászka 2015; Rómer 1870, 17, 18). Levický Lekárnický spolok spolu s E. Bolemanom sa aktívne zapojili do organi-

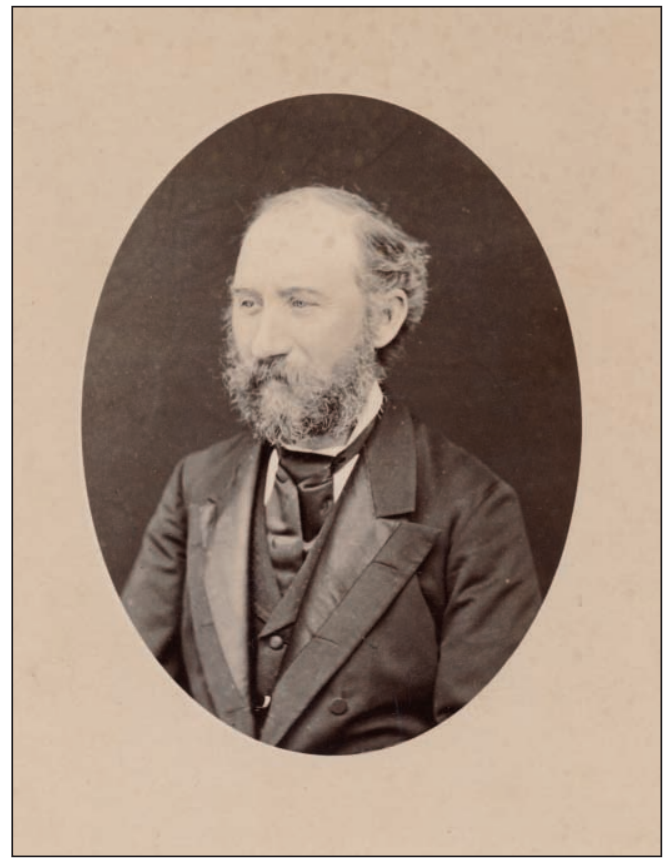

Obr. 2. Ede Boleman (1835-1884). začných prác VIII: medzinárodného kongresu antropológie a prehistorickej archeológie (Prohászka 2015a). $\mathrm{Z}$ tohto dôvodu archeologickú zbierku poslali na výstavu realizovanú k danej udalosti v Budapešti. Na druhej strane sa podielali aj na organizovaní návštevy pozvaných hostí sledovaného podujatia priamo v Mad’arovciach, kde okrem pohostenia 12. septembra v poludňajších hodinách priamo na lokalite uskutočnili krátkodobý výskum (Henszlmann 1876, 263, 264; Prohászka 2015b). Časṫ vystavených artefaktov ako aj počas výskumu objavené predmety darovali organizátori zahraničným hostom kongresu (Henszlmann 1876, 263). Výskum E. Bolemana v Domaníkoch koncom augusta 1876 bol vyvolaný práve s prípravnými prácami kongresu. Z nájdených urien poslal niekol'ko kusov aj F. Rómerovi, ostatné nálezy mienil vystavit na výstave, ktorú organizovali pri príležitosti návštevy účastníkov kongresu v Mad’arovciach (b. a. 1876). Výskumnú správu E. Boleman neposlal organizačnému výboru, resp. F. Rómerovi, ale publikoval ju v denníku Hon (Vlast') v článku pod názvom „Régészeti leletek Hontmegyében“/Archeologické nálezy v Hontianskej stolici (b. a. 1876):

„Léváról Boleman Ede gyógyszerész úrtól a következő érdekes sorokat veszszük: A régészek figyelmét e sorokkal arra akarom felhívni, hogy ásatásokat eszközöltessenek Domanikon Hontmegyében, mely kis község a Terény-selmeczi-út mellett Némethi városka elött fekszik. E helységtöl alig 8-10 percznyi távolságban, az országúttól 15-20 ölnyire a Selmecz folyó 1-öl magas partjában 1 és 1 1⁄2 lábnyi mélységben kövek alatt kisebb s nagyobb urnák találhatók. Ezek telvén hamu, szén és csontdarabokkal. Ily urnákat találtam egy-két előbbi ásatásom alkalmával; 29-én uj kirándulást tettem Broch föorvos urral s fáradságunkat szép eredmény jutalmazta. Ezen helyen barbárkori temetkezési hely lehetett, de az árvizek folytán a magasabb helységböl legördülő kövek által az urnák legnagyobb része fel van forgatva s összezuzva s csak elvétve találni egészeket. Egyik urnában a csontok felett bronz fibulát és karperecznek részeit találtuk, de az ércz már tökéletesen drugo nobilis-sé átváltozva. Ez azt mutatja, hogy ezen temetkezési hely a kőkor és a bronzkor átmeneti korszakába esik. Most Keller Rezső németh-i körjegyző urnál láttam egy egész ép urnát szintén telve hamuval és csontokkal és tetején kövésővel, melyet egy paraszt a folyó partján a leomlott földben talált ép állapotban, s ezt a jegyző urnak adta át, míg egy másikat összezuzott azt hívén, hogy aranyat talál benne. Mult alkalommal folytatott ásatásomkor egyik urna mellett kova szilánkot leltem, tegnap átfurt cserép sulykot, az ugynevezett orsót. Valószinü, ezen völgyben is ugyanazon népfaj tanyázott, mint Mogyoródon, hol áldozó helyük 
volt. Sốt Szudon, F.-Gyarmathon s nagyobbára a közelfekvó völgyekben mindenütt cserépdarabok találhatók. A lelt tárgyakból nehány darabot leküldtem volt dr. Rómer Flóris urnak a többit pedig kiállitjuk Mogyoródon september hó 12-én, midőn az östörténelmi congressus tagjai Mogyoródra is kirándulnak, megtekintendók Mogyoródot, e híres áldozó helyet, valamint azon tégla- vagy agyagutat, mely a Dunától - Szobbtól egész fel a bányavárosokba vihetett, melynek nyomai láthatók. Helembánál Szobb mellett, Szudon t. Sembery imre úr parkjában vagy 600 ölre ép állapotban fenntartva és Zsemberen a cserepesi pusztán már csak mint elmállott tégla- vagy agyagárok, mely vörös szalagként vonul végig szud felé, s följebb Pécsergicz felé az erdőben elvész. - Bars-és Hontmegye föispánjai a bars-hontmegyei gyógyászati egylet által felkérettek, hogy september hó 12-én, midőn a congressus tagjai Mogyoródra kirándulnak, intézkedni kegyeskedjenek, hogy szobon fogatok legyenek s hívják föl a megye intelligentiáját a részvételre. Mint tudomásomra jutott, a föispán urak készséggel feleltek meg. Máris intézkedtek, hogy a tudósok fogadtatása Mogyoródon ünnepélyes legyen. Az egylet pedig addig és az napon is folytatva ásatásait a kiránduló vendégeknek bizonyára sok becset és tanulságot lesz képes nyujtani."

Podávame volný štylisticky upravený preklad príspevku:

„Z Levíc od pána lekárnika Ede Bolemana sme dostali nasledovné zaujímavé informácie.

Uvedenými riadkami dávam na vedomie archeológom, aby realizovali archeologické vykopávky v Domaníkoch, v hontianskej stolici. Malá obec sa nachádza pred mestečkom Hontianske Nemce, vedla hradskej vedúcej z Terian do Banskej Štiavnice. Vo vzdialenosti sotva 8-10 minút chôdze od obce, 15 až 20 siah od hradskej na siahu vysokom brehu Štiavnického potoka, v híbke 1 až 1,5 stopy možno pod kameňmi nájst’ menšie - väčšie urny. Tie sú plné popolom a úlomkami kostí. Takéto urny som našiel počas jedného až dvoch predchádzajúcich výskumov. Dňa 29. augusta 1876 počas výletu s primárom Brochom bola naša námaha bohato odmenená. Na uvedenej lokalite zrejme bolo barbarské pohrebisko, ale $\mathrm{v}$ dôsledku povodní $\mathrm{z}$ vyšších miest sa skotúlali kamene, ktoré zväčša rozbili a povalili urny. Z nich celé exempláre možno nájst' iba výnimočne. $V$ jednej urne sme nad kostami našli bronzovú sponu a časti náramku, pričom kov už bol dokonale patinovaný. Uvedené skutočnosti poukazujú nato, že skúmané pohrebisko pochádza z rozhrania doby kamennej a bronzovej. Nedávno som videl u okresného notára Rezső Kellera jednu celú zachovalú urnu, ktorá bola plná popola a kostí nad ktorými sa nachádzalo kamenné dláto (plochá sekerka). Uvedenú nádobu našiel v brehu potoka miestny rolník, ktorý ju odovzdal pánovi notárovi. Druhú urnu ale roztíkol, domnievajúc sa, že v nej nájde zlato. Počas minulého výskumu som vedla jednej urny našiel úštep z kremeňa, včera zas prevŕtané závažie, tzv. praslen. Domnievame sa, že i v tomto údolí sa usadilo podobné etnikum ako v Madarovciach, ktoré však tam malo svoje obetisko. Dokonca aj v Sudinciach a v Hontianskej Vrbici a zväčša i v blízkych údoliach možno všade nájst’ črepy. Z nájdených predmetov som niekol'ko kusov poslal dr. Flórisovi Rómerovi, ostatné zas vystavíme v Madarovciach 12. septembra z príležitosti návštevy účastníkov prehistorického kongresu, ktorí tam obhliadnu známe obetisko a spečené valy tiahnuce sa od Szobu po banské mestá. Zvyšky uvedeného valu vidno v Chlabe blízkosti Szobu, Sudinciach v parku pána Imreho Semberyho v pomerne zachovalom stave v dížke 600 siah a Žemberovciach v osade Cserepes (dnes Čriepeš), kde je už zvetraný a odtial' sa tiahne v podobe červenej stuhy (pásu) smerom do Sudiniec a vyššie v Pečeniciach sa stráca v lese. Hlavný župan Tekovskej a Hontianskej stolice prostredníctvom tekovskej a hontianskej lekárnickej spoločnosti ma požiadali, aby 12. septembra, v čase príchodu účastníkov kongresu do Mad’aroviec, zaistil prítomnost’ záprahov v Szobe na presun hostí a vyzval aj miestnu inteligenciu $\mathrm{k}$ návšteve podujatia. Dozvedel som sa, že hlavní župani sa pozitívne postavili k tejto akcii. Okamžite nariadili, aby v Mad’arovciach bolo privítanie vedcov slávnostné. A zároveň aby lekárnický spolok v ten deň pokračoval vo výskume za účelom poskytnutia poznatkov a zážitkov pre prichádzajúcich hostí."

Táto Bolemanova správa bez udania zdroja bola zverejnená v slovenčine v roku 1876 prvom ročníku Slovenského letopisu, v zošite 4, ktorej autorom je F. V. Sasinek $(1876,334)$.

Miesto uloženia nálezov, ktoré E. Boleman poslal F. Rómerovi sa nám nepodarilo zistit', pretože $v$ knihe prírastkov Madarského národného múzea neboli zaznamenané ani ako dar Bolemana ani s pomenovaním lokality. Vo vitríne výstavy boli umiestnené iba Bolemanove nálezy z Madaroviec a Kalnej nad Hronom (Hampel 1876, 53). Nemožno však vylúčit, že darovanými predmetmi F. Rómer zveladil archeologickú zbierku budapeštianskej univerzity, čo však v dôsledku absencie inventárnej knihy nemožno kontrolovat.

E. Bolemanom spomínaná urna, ktorú uschovával okresný notár R. Keller, sa naštastie nestratila. O pár mesiacov neskôr, vo februári 1877, sa objavila správa v časopise Archaeológiai Értesítő, ktorá informuje o dare R. Kellera pre Národné múzeum v Budapešti (Rómer 1877, 9): „Od okresného notára Rezső Kellera sme dostali: 1 kamenný amulet; 1 kamenné dláto (plochá sekerka); jelení paroh; 1 bronzové náradie a zdobená urna s grafitovým povlakom a lineárnou výzdobou. Miesto nálezu: Domaníky (Hontianska stolica)."V Mad’arskom 
národnom múzeu 15. februára 1877 inventarizovali nasledovné nálezy získané darom R. Kellera z Hontianských Nemiec:

1. Kamenný amulet, dí. 7,7 cm; š. 2,2 cm (MNM 18/1877. 1). Sebechleby (Hontianska župa).

2. Kamenné dláto (plochá sekerka), dí. 13,8 cm; š. 4,5 cm; hr. 3,7 cm (MNM 18/1877, 2). Sebechleby (Hontianska župa).

3. Jelení paroh, dl. 27,5 cm s lešteným a tenko zarezávaným hrotom (MNM 18/1877, 3). Sebechleby (Hontianska župa).

4. Bronzový nástroj podobný puzdra pre dýku. Dí. 21,5; max. š. 5,1 cm. Hrubo spájkované z dvoch častí (MNM 18/1877, 4). Sebechleby (Hontianska župa).

5. Urna vonku potiahnutá grafitovým povlakom, zdobená líniami, opatrená dvoma malými uchami. Vo vnútri kostami premiešaná hlina. V. 17,9 cm; pr. ú. 13 cm (MNM 18/1877, 5). Domaníky (Hontianska župa).

\section{URNA Z DOMANÍK}

Sivastá dvojuchá amfora s vodorovne vyhnutým krátkym okrajom s kónickým prehnutým hrdlom, ktoré plynulo prechádza do pliec. Zaoblené vydutie je stlačené, kónická spodná čast’ opatrená s rovným mierne odsadeným dnom. Dve protilahlé pásikové uchá sú nasadené na pleciach, tesne nad vydutím. Výzdobu hrdla tvorí šest̉ obežných vodorovných žliabkov. Na rozhraní pliec a tela zdobená štyrmi obežnými žliabkami. Horná čast tela nádoby po celom obvode je krášlená hustými a širokými zvislými, pod uchami mierne zošikmenými žliabkami s dolným ukončeným do stratena. Plece zdobili piatimi malými kruhovými jamkami usporiadané do poloblúka a obrazcami, ktoré vytvára jeden dlhší šikmý žliabok v kombinácii šiestich kolmo nasadených kratších žliabkov. Rozmery: v. 16,5 cm; pr. ústia 12,6 cm; pr. dna $8,6 \mathrm{~cm}$; pr. vydutia $21,5 \mathrm{~cm}$; š. ucha $1,8 \mathrm{~cm}$. Kostami premiešaná hlina uvádzaná v prírastkovej knihe sa už nenachádza v nádobe. Inv. č. MNM 18/1877. 5 (obr. 3).

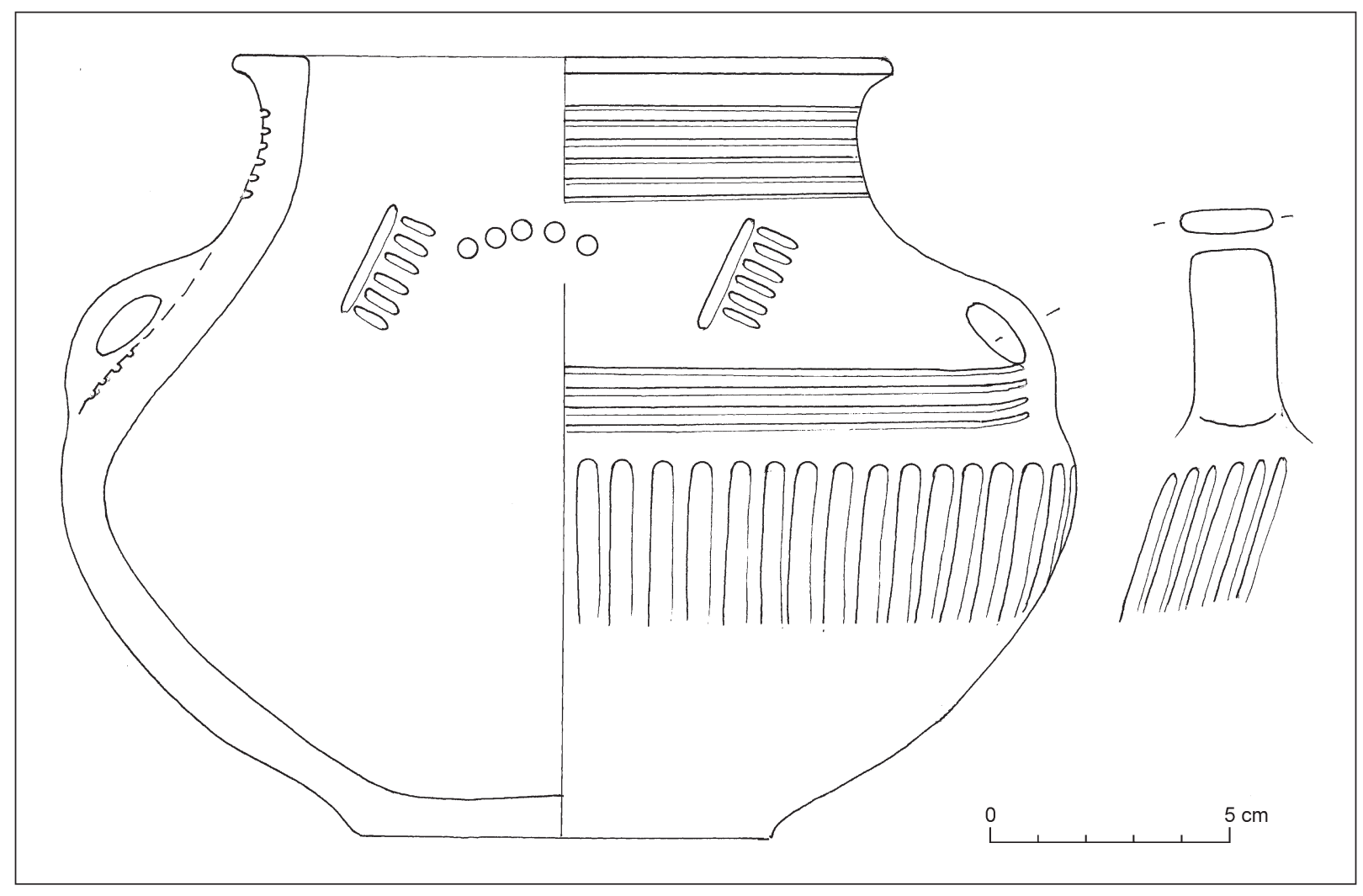

Obr. 3. Urna z Domaník v zbierke Mad’arského národného múzea. 
Sledovaná nádoba vel'mi pravdepodobne pochádza z pohrebiska, ktoré ako prvý skúmal svojho času E. Boleman a následne aj A. Kmet' (Bátora 1979, 60, 61; Borovszky 1906, 279; b. a. 1876; Kmet' 1895; Polla 1996, 137, 138; Sochán 1888; Veliačik 1978, 36, 37). Lokalita v polohe Konopiská sa nachádza 600 m juhozápadne od obce, tesne na pravom brehu Štiavnice. $Z$ typologického aspektu relatívne blízku analógiu k sledovanej amfore našli v Ilave, v hrobe 281 a zároveň reprezentuje nimi vyčlenený typ A2. Podla autorov sledovanej monografie tektonikou sa tento typ podobá amforám lužickej kultúry na Morave, najmä do základného (4. fáza) stredného (sliezkého) obdobia, teda z HB1 (Benediková/Katkinová/Budinský-Krička 2016, 177, obr. 94: 281). Ďalšia typologicky blízka amfora sa našla na pohrebisku Žitavany-Kňažice v hrobe 29, ktorú autor výskumu dokonca považuje za import zo sídelnej oblasti kyjatickej kultúry (Kujovský 2018, 246, 274, tab. XV: 2). Zomrelých na sledovanej lokalite pochovávali od záveru mladšej doby bronzovej po prvú polovicu neskorej doby bronzovej (HA2-HB1; Kujovský 2018, 287).

Chronologické postavenie žiarového pohrebiska v Domaníkoch v rámci dlhého vývoja lužickej kultúry na Slovensku definovali viacerí bádatelia. Podla L. Veliačika $(1978,36,37)$ v keramickom materiáli je evidentný vplyv z oblasti kyjatickej kultúry. Z bronzovej industrie sa objavili špirálovité prstene, zlomok sedlovitej spony, nakrčný kruh s tordovaným telom a koncami stočenými v očko, zlomok ihlice s hlavicou stočenou v očko (Veliačik 1978, 37).

Pohrebisko v Domaníkoch spolu s nálezmi z Lišova J. Bátora $(1979,69)$, datuje rámcove do stupňa HB. Záverom možno ešte poznamenat', že nedatované urny sa našli aj v intraviláne Domaník okolo kostola (Gyürky 1883, 160).

\section{BANÍCKY PRACOVNÝ NÁSTROJ, TZV. ŠPICIAK ZO SEBECHLIEB}

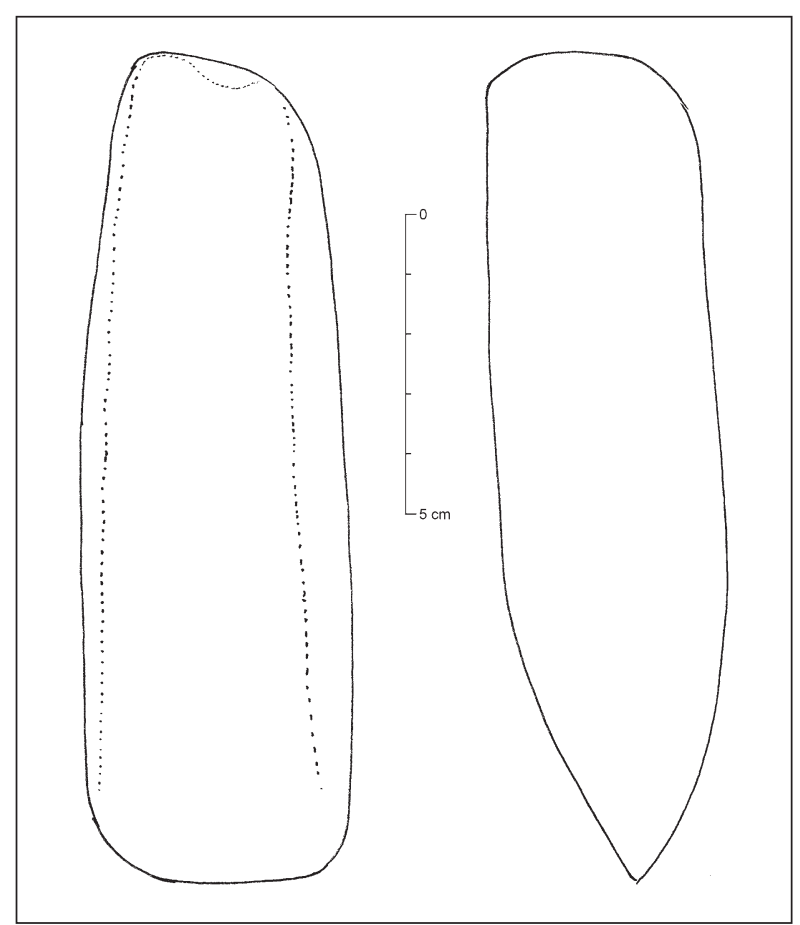

Obr. 4. Brúsená kamenná industria zo Sebechlieb.
R. Keller okrem urny poslal ešte štyri predmety do Madarského národného múzea, ktoré sa našli v katastri obce Sebechleby, okr. Krupina. Kamenný amulet a jelení paroh dnes už nemožno identifikovat' v nálezovom fonde. Popri plochej kamennej sekerke (dí. $14 \mathrm{~cm}$; š. 4,5 cm; hr. 3,8 cm; obr. 4) si nepochybne mimoriadnu pozornost' zasluhuje bronzový artefakt na boku s recentne vyrytým nápisom "Szebelléb", čo je totožný so súdobým mad’arským názvom obce Sebechleby.

Ide o liaty dutý bronzový postupne zúžený podlhovastý hranatý špiciak s tulajkou a so zaobleným hrotom. Bol pospájaný z dvoch samostatne odliatych polovíc. Tri steny otvoru pre porisko sú rovné, jedna dlhšia stena je zaoblená. Rozmery otvoru tulajky: 3,9 x 2-2,6 cm. Celková dížka 21,5 cm; rozmery oválneho ústia 5,4 x 3,5 cm. Inv. č. MNM 18/1877.4 (obr. 5).

Sledovaný predmet svojho času publikoval J. Hampel, pričom správne definoval aj jeho funkciu, banícky nástroj (Hampel 1892, 139). Vo svojom texte uvádza, že predmet daroval v roku 1877 R. Keller a opisuje ho ako valcovitý banícky nástroj dlhý $21,5 \mathrm{~cm}$ s tulajkou s priemerom $8,1 \mathrm{~cm}$. Ten istý údaj sa nachádza aj vo francúzsky publikovanej knihe i ked' v tomto prípade predpokladá, že pochádza z depotu (Hampel 1886, 99, tab. XV). V tretom zväzku, v mad’arsky publikovanej knihe, dokonca zverejňuje aj jeho kresbu, ale bez popisného textu (Hampel 1896, 32, obr. 3). Absencia textu pod kresbou, resp. na nevhodnom mieste umiestnený odkaz zapríčinili, že uvedený nález zo Sebechlieb zostal odborníkmi nepovšimnutý. Žial, o konkrétnom mieste nálezu a o nálezových okolnostiach nemáme $\mathrm{k}$ dispozícii relevantné informácie. 


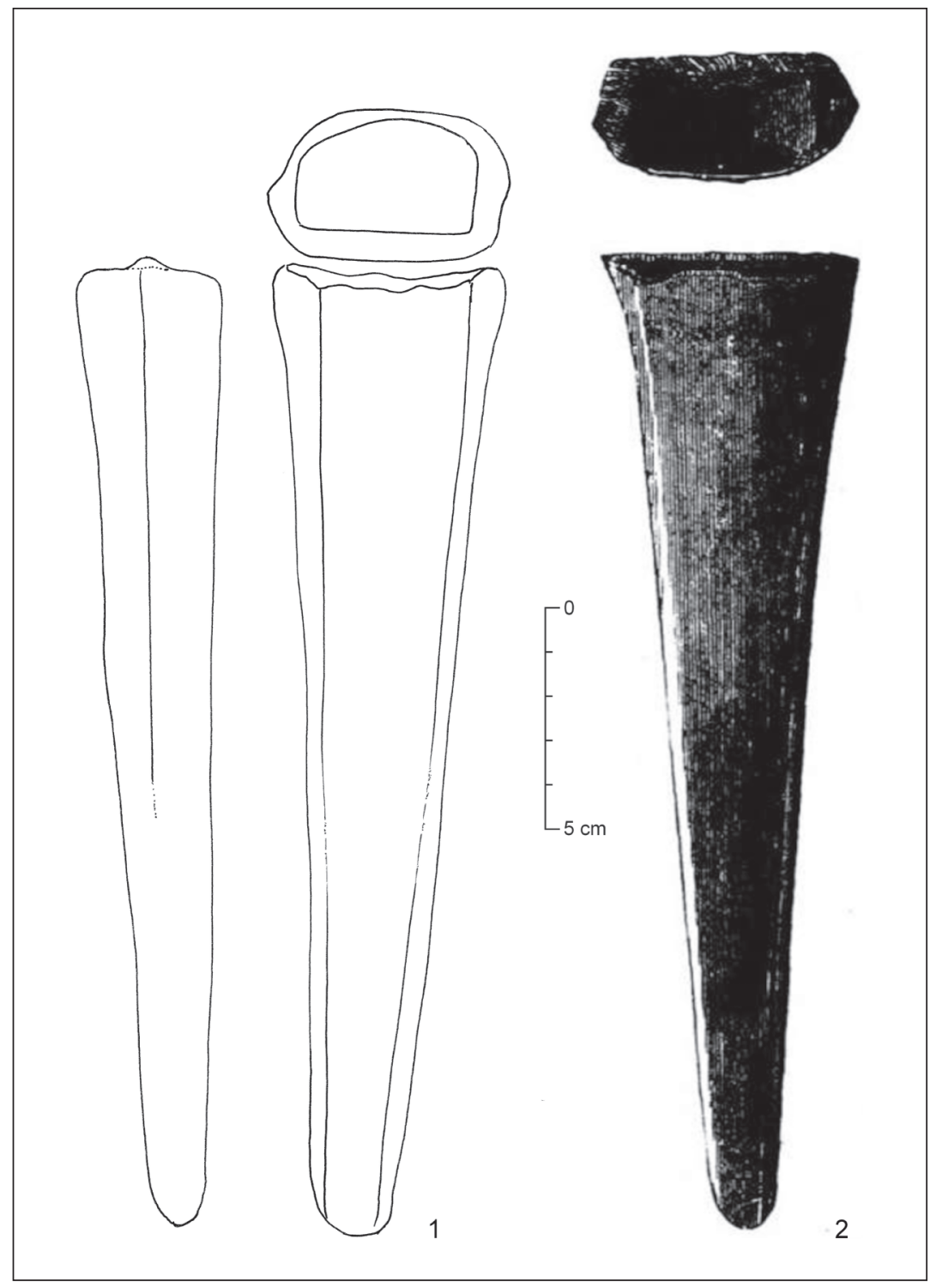

Obr. 5. Bronzový špiciak s tul'ajkou zo Sebechlieb. 1 - kresba J. Marettová; 2 kresba z knihy J. Hampla (1896, 32, obr. 3).
V katastri Sebechlieb sa na viacerých miestach našli archeologické nálezy. Na svahu pod "Malou Horou“ bolo počas vinohradníckych prác narušené pohrebisko, z ktorých pochádzajú črepy viacerých lužických nádob. Najčastejšie sú črepy baňatých amfor s kuželovitým hrdlom a vydutím zdobeným zvislými i vodorovnými ryhami, skupinami jamiek a výčnelkami. Pôvodne sa našli aj bronzové predmety, ktoré sa stratili (Balaša 1960, 51; Kmet’ 1905, 56; Veliačik 1978, 132).

Nález baníckeho nástroja v Sebechleboch nie je prekvapivý, pretože kataster samotnej obce leží na úpätí Štiavnických vrchov, ktoré majú vulkanický pôvod. Najbližší výskyt oxidačných rúd medi je evidovaný v katastroch Pukanca, okr. Levice, Banskej Štiavnice, okr. Banská Štiavnica, Hodruši-Hámrov, okr. Žarnovica, Banskej Belej, okr. Banská Štiavnica a Vyhní, okr. Žiar nad Hronom (Bátora 2018, obr. 267). Sekundárne ložiská zlata sú zaznamenané na území obcí Pukanec, v polohe Pukanský potok, okr. Levice, Žemberovce, okr. Levice Ladzany, okr. Krupina, Hontianske Nemce, okr. Krupina a Prenčov, okr. Banská Śtiavnica (Bátora 2018, obr. 269).

Z doby bronzovej sa okrem sledovaného nálezu zo Sebechlieb zatial’ nevyskytol z územia Slovenska iný bronzový artefakt, ktorý by definovali ako banícky nástroj. Podobná je však situácia v susedných aj vzdialenejších oblastiach. V Karpatskej kotline sú łzv. špiciaky pomerne vzácne. Evidujeme ich v dvoch obrovských bronzových depotoch v Sedmohradsku, a to na lokalitách Guşterița, dnes miestna čast̉ mesta Sibiu (Petrescu-Dîmboviţa 1978, 120-122; tab. 113: 211), a Uioara de Sus, dnes miestna čast̉ mesta Ocna Mureşului, jud. Alba (Petrescu-Dîmbovița 1978, 132-135, tab. 165: 119-123). V týchto prípadoch však ide o typologicky úplne odlišné exempláre používané hlavne pri tažbe soli, ktoré sú v hornej časti opatrené až štyrmi vonkajšími lalokmi. Sledované depoty patria do tzv. druhého stupňa mladšej doby bronzovej (zweite Jungbronzezeitstufe), sedmohradského horizontu Suseni, ktorý možno synchronizovat' so zadunajským horizontom Kisapáti-Lengyeltóti (Petrescu-Dîmboviţa 1978, obr. 3) a na Slovensku s horizontom Martinček-Bodrog datovaným do HA1 (Novotná 1970, 12-15, tab. 1). Do sledovanej kategórie baníckych špiciakov zrejme patrí aj unikátny, zatial' nepublikovaný bronzový artefakt, ktorý bol súčastou depotu v keramickej nádobe na mohylovom pohrebisku v Krteloch (južné Čechy), o ktorom referoval O. Chvojka ${ }^{2}$ na XV. medzinárodnej konferencii doba popolnicových polí a doba halštatská v Smoleniciach (Mitáš 2018,

Za informácie a fotografiu špiciaka z Krtel d’akujeme O. Chvojkovi. 
381

PRÍSPEVOK K DEJINÁM VÝSKUMU LOKALÍT Z DOBY BRONZOVEJ V DOMANÍKOCH A SEBECHLEBOCH

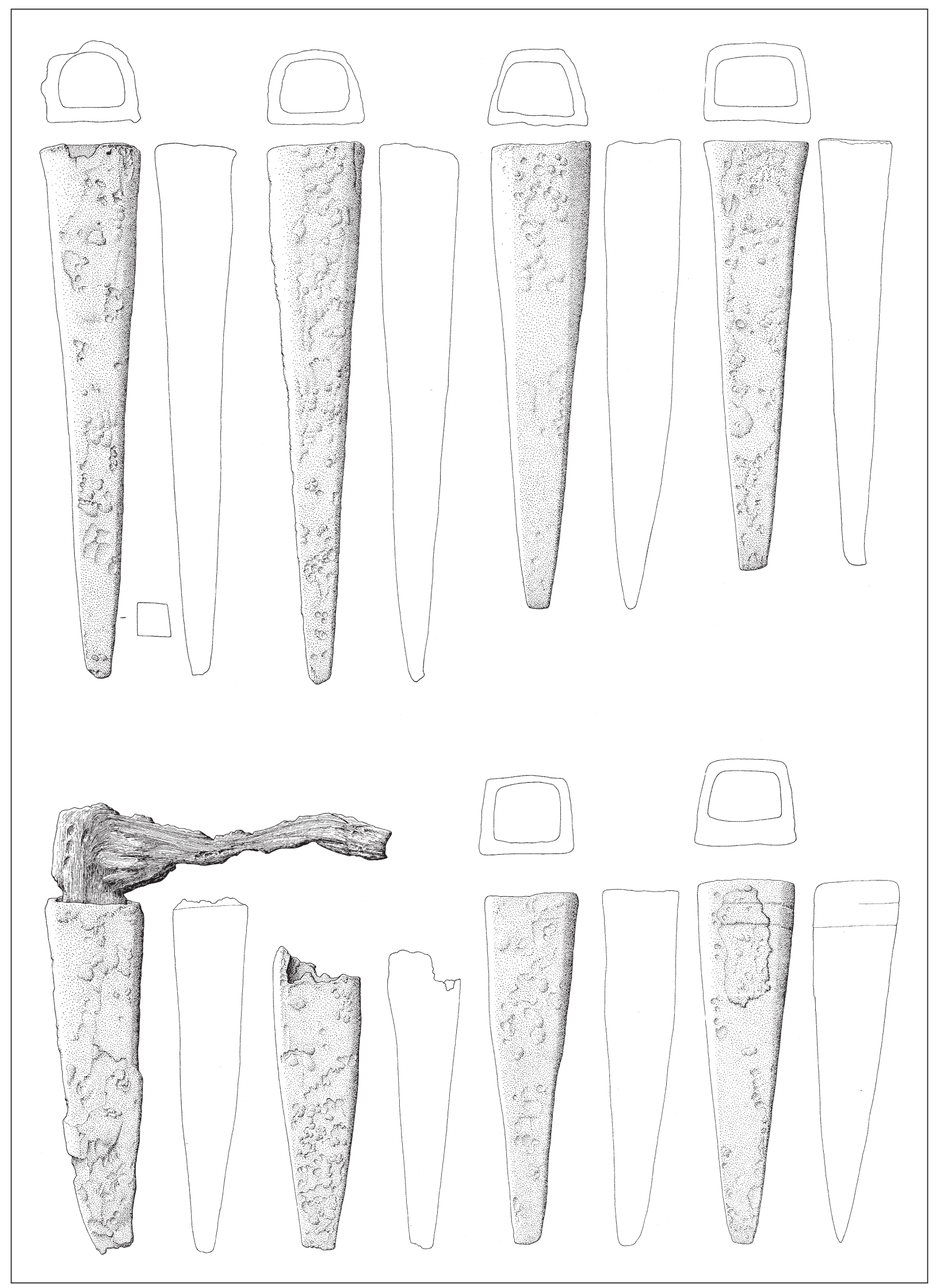

Obr. 6. Špiciaky z rakúskeho Mittebergu (Mayer 1977, tab. 91). 
375). Pravdepodobné fragmenty hrotov, tzv. špiciakov evidujeme ešte zo Zakarpatskej oblasti Ukrajiny z nejednoznačne určenej lokality - Velikaja Began, Zmeevka alebo Orosievo, okr. Beregovo (Kobal' 2000, 98, tab. 94B: 5), prípadne z Holašovíc, okr. České Budějovice (Kytlicová 2007, 262, tab. 21: 22).

Relatívne blízke analogické nálezy $\mathrm{k}$ tzv. špiciaku zo Sebechlieb nachádzame na území západného Rakúska, v spolkovej krajine Vorarlbersko, na lokalite Mitteberg (obr. 6), kde podobné predmety definujú ako Tüllenpickel der Mitteberger Form (Mayer 1977, 226, tab. 90: 1342-1344; 91: 1345, 1346; Reschreiter/Konrad 2018). Sú zastúpené aj v depote (obr. 7) z priesmyku Lueg (Mayer 1977, 227, tab. 124: 5), ktorý datujú do staršieho obdobia popolnicových polí, prípadne do stupňa Haidach/Draßburg (Mayer 1977, 227).

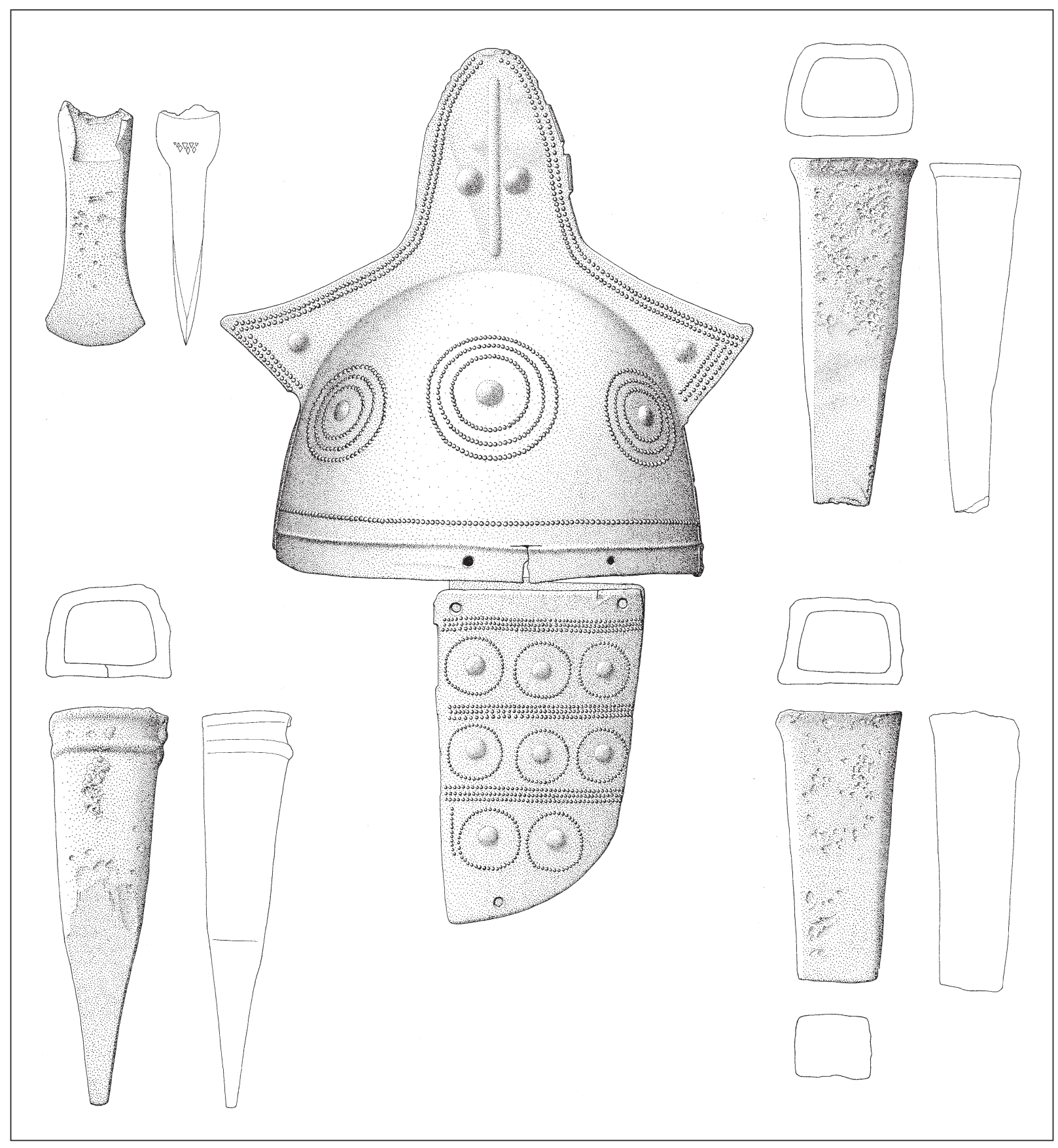

Obr. 7. Depot z priesmyku Lueg (Mayer 1977, tab. 124). 
Záverom možno konštatovat', že prvý staronový banícky nástroj, tzv. špiciak zo Sebechlieb, sa našiel na sídelnom území lužickej kultúry v tesnej blízkosti Štiavnických vrchov s bohatými ložiskami rôznych farebných kovov. Vzhladom na to, že ide pravdepodobne o solitérny nález bez bližších nálezových okolností, presnejšie datovanie $\mathrm{v}$ rámci relatívne dlhého a komplikovaného vývoja lužickej kultúry by bolo zavádzajúce. Doposial' známe nálezy sledovaného predmetu pochádzajúce z bronzových depotov sú datované do staršieho stupňa popolnicových polí, prípadne horizontu Suseni/Kisapáti-Lengyeltóti alebo Martinček-Bodrog.

\section{LITERATÚRA A PRAMENE}

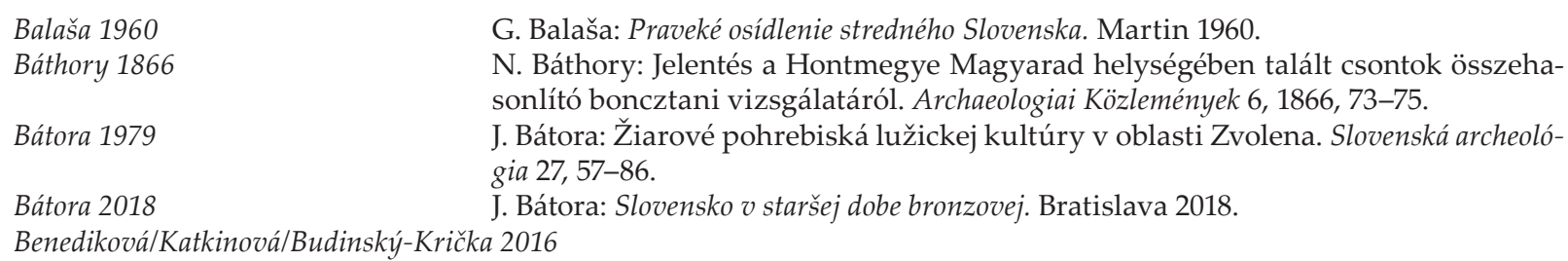

L. Benediková/J. Katkinová/V. Budinský-Krička: Ilava, poloha Porubská dolina Pohrebisko lužickej kultúry na strednom Považí. Bratislava - Nitra 2016.

Boleman 1870

Borovszky 1906

Gyürky 1883

Hampel 1876

Hampel 1886

Hampel 1892

Hampel 1896

Henszlmann 1876

Kmet' 1895

Kmet' 1905

Kobal' 2000

Kujovský 2018

Kytlicová 2007

Mayer 1977

Mitáš 2018

Nevizánsky/Prohászka 2015

Novotná 1970

Petrescu-Dîmbovița 1976

Polla 1996

Prohászka 2015a

Prohászka $2015 b$

Prohászka 2018

Reschreiter/Konrad 2018

Rómer 1870
E. Boleman: Archaeologiai levelek VIII. Archaeologiai Értesítő 2, 1870, 107, 108.

S. Borovszky: Hont vármegye. Magyarország vármegyéi és városai. Budapest 1906.

A. Gyürky: Ötvennégy év Hontvármegye történetéből 1820-tól 1874-ik. II. kötet. Vácz 1883.

J. Hampel: Catalogue de l'exposition préhistorique des musées de province et des collections particuliéres de la Hongrie. Budapest 1876.

J. Hampel: Trouveálles de l'âge de bronze en Hongrie. Budapest 1886.

J. Hampel: A bronzkor emlékei Magyarhonban 2. Budapest 1892.

J. Hampel: A bronzkor emlékei Magyarhonban 3. Budapest 1896.

J. Henszlmann: A történelem előtti és embertani VIII. Nemzetközi congressusnak Budapesten tartott ülései és kirándulásai. Archaeologiai Értesítő 10, 1876, 237-255.

A. Kmet: Starožitnosti v Honte. Tovaryšstvo 2, 1895, 195-214.

A. Kmet: Popolnicové polia z d’alšieho okolia Sitna. Časopis Muzeálnej slovenskej spoločnosti 8, 1905, 56, 57.

J. V. Kobal: Bronzezeitliche Depotfunde aus Transkarpatien (Ukraine). Prähistoriche Bronzefunde XX/4. Stuttgart 2000.

R. Kujovský: Pohrebisko z doby popolnicových polí v Žitavanoch-Kňažiciach. Slovenská archeológia 66, 2018, 235, 336.

O. Kytlicová: Jungbronzezeitliche Hortfunde in Böhmen. Prähistoriche Bronzefunde XX/12. Stuttgart 2007.

E. F. Mayer: Die Äxte und Beile in Österreich. Prähistorische Bronzefunde IX/9. München 1977.

V. Mitáš: XV. Medzinárodná konferencia. Doba popolnicových polí a doba halštatská. Slovenská archeológia 66, 2018, 374-379.

G. Nevizánsky/P. Prohászka: K počiatkom výskumu eponymnej lokality mad’arovskej kultúry v šest'desiatych rokoch 19. storočia. Zborník na pamiatku Jozefa Paulíka. Zborník SNM. Supplementum 9. Bratislava 2015, 35-51.

M. Novotná: Die Bronzehortfunde in der Slowakei. Spätbrozezeit. Bratislava 1970.

M. Petrescu-Dîmbovița: Die Sicheln in Rumänien mit Corpus der jung-und spätbronzezeitlichen Horte Rumäniens. Prähistoriche Bronzefunde XVIII/1. München 1978.

B. Polla: Archeológia na Slovensku v minulosti. Martin 1996.

P. Prohászka: Rómer Flóris és a budapesti VIII. Ősrégészeti és Embertani Kongresszus előkészületei - Flóris Rómer and the preparations of the $8^{\text {th }}$ Congress of Prehistoric Archaeology and Anthropology of Budapest. Arrabona 51, 2015, 87-114.

P. Prohászka: Rómer Flóris és a VIII. Ôsrégészeti és Embertani Kongresszus Budapesten. In: T. Kerny/Á. Mikó (red.): Archaeológia és mütörténet. Tanulmányok Rómer Flóris munkásságáról születésének 200. évfordulóján. Budapest 2015, 77-102.

P. Prohászka: A Hontmegyei Ritkaságokat Gyűjtő Társulat régészeti leltára és tevékenysége. Honismeret 46, 2018, 29-36.

H. Reschreiter/M. Konrad: Keine Tüllenpickel im bronzezeitlichen Salzbergbau von Hallstatt! Experimentelle Archäologie in Europa 17, 2018, 19-33.

F. Rómer: Újabb leletek. Archaeologiai Értesítő 2, 1870, 16-19. 
Rómer 1877

Sasinek 1876

Socháň 1888

Veliačik 1978

b. a. 1876

b. a. 1884
F. Rómer: Hazai tud. Intézetek és leletek. Archaeologiai Értesítő 9, 1877, 95-99.

F. V. Sasinek: Starožitnosti u Domaníku. Slovenský letopis 1, 1876, 334.

P. Socháň: Neco o pohrebišti u Domaník. Časopis Vlasteneckého Muzejního Spolku Olomouckého 5, 1888, 80-82.

L. Veliačik: Lužická kultúra na Slovensku. Diel II. Kandidátska dizertácia (Archeologický ústav SAV). Nitra 1978. Nepublikované.

b. a.: Régészeti leletek Hont megyében. Pesti Napló 27, Nr. 210, 1876.

b. a.: Boleman Ede. Bars 4, Nr. 39, 1884.

\title{
Beitrag zur Forschungsgeschichte bronzezeitlicher Fundorte in Domaníky und Sebechleby
}

\author{
Gabriel Nevizánsky - Péter Prohászka
}

\section{Zusammenfassung}

Dass das im Komitat Hont befindliche Dorf Domaníky in der archäologischen Literatur bekannt wurde, ist Andrej Kmet’ zu verdanken. Im Jahre 1887 legte Kmet’ hier einige Gräber eines früheisenzeitlichen Gräberfeldes frei. Er veröffentlichte im zweiten Band von „Tovaryšstvo” sowohl seine Grabungsergebnisse als auch die meisten Funde. Kmet' wird als erster Erforscher des Fundortes in der slowakischen Forschung genannt, obwohl schon mehr als ein Jahrzehnt vorher über die ersten Funde berichtet worden war, die sogar ins Ungarische Nationalmuseum gelangten. Im Sommer 1876 wurde dort auch eine kleine Ausgrabung durchgeführt. Der Notar R. Keller machte im Jahre 1870 F. Rómer bzw. die Archäologische Kommission auf die hier ans Tageslicht gekommenen Funde aufmerksam. Sechs Jahre später, Ende August 1876, besuchte der Laienforscher und Apotheker Ede Boleman aus Levice die Fundstelle und nahm eine kurze Ausgrabung vor. Seine Forschungen waren mit dem VIII. prähistorischen und anthropologischen Kongress verbunden, der zwischen 4. und 11. September 1876 in Budapest veranstaltet wurde. Sein Grabungsbericht erschien in der Tageszeitung „Hon” (Heimat) unter dem Titel „Archäologische Funde im Komitat Hont”. Er sandte einen Teil der Funde an F. Rómer, den anderen wollte er bei der kleinen Ausstellung anlässlich der Exkursion der Kongressteilnehmer in Magyarád (Mad’arovce) vorstellen. Der Bericht erschien slowakisch in der ersten Nummer von Slovenský letopis (1876), Seite: 334, jedoch ohne Nennung der Originalquelle. Die von Boleman an Rómer gesandten Funde gelangten aber nicht ins Nationalmuseum. Wahrscheinlich hat der Professor der Archäologie damit die Sammlung seines Lehrstuhles bereichert, was wir mangels weiterer Angaben nicht klären konnten. Boleman berichtete im Zeitungsartikel auch über eine Urne aus Domaníky, die sich im Besitz des Notars R. Keller befand. Im Februar 1877 schenkte Keller die Urne mit anderen prähistorischen Funden dem Ungarischen Nationalmuseum (UNM Inv.-Nr. 18/1877). Dabei handelte es sich um ein Steinamulett, einen Steinmeissel, ein Hirschgeweih und ein Bronzegerät in Form einer Hülse, die in Sebechleby gefunden worden waren. Nach Bolemans Bericht war die dem Museum geschenkte graue Urne mit eingedrückten Verzierungen am Ufer des Flusses zum Vorschein gekommen. Sie stammt höchstwahrscheinleich aus demselben Gräberfeld, das zuerst von Boleman, dann einige Jahre später von Kmet’ erforscht wurde. Die Fundstelle liegt ca. 600 Meter südöstlich vom Dorf, gleich auf dem rechten Ufer des Štiavnica- Baches, in der sogenannten Flur Konopiská. Die Urne ist typologisch mit dem Stück aus dem Grab 281 des Gräberfeldes von Ilava verwandt, die in den Typ A2 eingeordnet wurde. So können wir die Urne in Reinecke Ha B1 datieren.

Von den anderen eingesandten Gegenständen ausSebechleby befinden sichnurzwei-dieSteinaxtund das Bronzegerät - im Nationalmuseum. Das Bronzegerät hat die Form einer Dolchhülse und besteht aus zwei zusammengelöteten Stücken. Schon József Hampel hat seine Funktion als Bergbaugerät bestimmt. Aus Sebechleby sind mehrere Funde bzw. Fundorte bekannt, wie zum Beispiel Malá Hora, wo ein Gräberfeld der Lausitzer-Kultur gestört wurde. Das ins Nationalmuseum gelangte Gerät ist ein Tüllenpickel, der im Bergbau genutzt wurde. Sebechleby liegt am Fuss des Selmecer-Berges (Stiavnické vrchy), und in der Nähe befinden sich zahlreiche Fundorte von Kupfer- und Golderzen. Neben dem Stück von Sebechleby sind bisher keine Geräte vom bronzezeitlichen Bergbau in der Slowakei bekannt. Die besten Analogien des Pickels kommen in westlichen Österreich, im Land Vorarlberg, am Fundort Mitterberg vor. Dieser Typ wurde danach auch als Tüllenpickel der Mitteberger Form benannt. Einige solche Stücke waren im Hortfund vom Pass Lueg, der in die ältere Urnenfelderzeit bzw. in den Horizont der Bronzehorte von Haidach und Draßburg datiert wird. Der Tüllenpickel aus Sebechleby bezeugt Kontakte mit dem westösterreichischen Bergbau in der Spätbronzezeit. 
Abb. 1. Umgebung von Domaníky und Sebechleby auf der Karte der Zweiten Militäraufnahme.

Abb. 2. Ede Boleman (1835-1884).

Abb. 3. Urne aus Domaníky in der Sammlung des Ungarischen Nationalmuseums.

Abb. 4. Steingerät aus Sebechleby.

Abb. 5. Zeichnung des Tüllenpickels von Sebechleby: 1 - Zeichnung von J. Marettová; 2 - Zeichnung im Buch von J. Hampel (1896, 32, Abb. 3).

Abb. 6. Tüllenpickel vom Mitteberger Typ (Mayer 1977, Taf. 91).

Abb. 7. Der Hortfund vom Pass Lueg (Mayer 1977, Taf. 124).

Translated by Péter Prohászka Übersetzt von Péter Prohaszka

PhDr. Gabriel Nevizánsky, CSc.

Archeologický ústav SAV

Akademická 2

SK - 94921 Nitra

nraunevi@savba.sk
Dr. Péter Prohászka, Phd.

Archeologický ústav SAV

Akademická 2

SK - 94921 Nitra

prohaszkapeter@freemail.hu 
